\title{
Bolivia and the Vicuna
}

\section{By J. J. C. Mallinson}

IN the Panagra Airlines booklet, issued to each tourist flying to Bolivia, heading the "What to Buy" column, are vicuña coats and rugs. In Bolivia there is no pretence that any animal is protected, or that any area has been set aside as a national park. The vicuña and the chinchilla are on a restricted list, but I was unable to find out what this involved. In La Paz I learned from reliable sources that in some regions machine guns were used on the vicuna, which illustrates the typical attitude to wildlife of the average Bolivian.

There is no restriction on the export of vicuna wool or wool waste. The price of the wool, or at least its export value, is at present 2.2 US dollars per kilo, on which since 1961 the government has levied a 15 per cent. export tax. There was some mention by the Ministero de Hacienda of a restriction on the total annual export figure, and also on persons allowed to shoot vicuña, but I was unable to find anything in black and white about this. Vicuña wool is still being smuggled from Peru, and is welcomed in Bolivia for the tax levied on its reexport. The local manufacturers of vicuña cloth are known to lubricate financially any hitch in this process of slaughter and smuggling. One Bolivian, more conservation-minded than most, told me that a lot of vicuña fleece was collected by driving the herds through cactus, and then collecting the entangled wool.

Professor Gaston Bejarano, a trained zoologist working with the Division de Empresas, Programa Forestal Corporacion Boliviana de Fomento, told me that ideally Bolivia should have two national parks. One should be for the vicuña, around Mount Sajama in the Altiplana department of Oruro, where they are still quite plentiful, and where the semi-arid rolling grasslands and plains produce the low perennial grasses which constitute almost their entire diet. The second should be around Lake Colorada, Sur Lipez, on the Chilean border, where both the James and Andean flamingos can be seen in abundance and are at present unmolested. The spectacled bear in the Andes should also be protected, especially in the Pie de Monte region of Bolivia.

The general indifference about the future of wildlife is the same in Bolivia as Ambassador Crowe found in other parts of South America and described in ORYX (April 1965). Interest in wild animals is only stimulated if there is an end product by way of skin or edible meat. The future of conservation in South America, as the Ambassador says, depends primarily on education. Through education people can be brought to want to see live animals, as they do in Africa, and tourism would help to finance wildlife protection. If the Bolivians could see that by creating reserves they would gain financially, they would enforce protection. Bolivia relies almost entirely on United States aid. By declaring these two reserves and providing suitable tourist accom- 
modation on the African model, she could increase her own tourist potential. But, alas, aid would have to come from outside even for setting up these reserves.

But unless the Bolivian revolutionises his attitude, the wildhife of the Altiplano and plains will gradually disappear, and the small animals in the remoter jungles will be the only survivors.

\section{Vicuna Reserve in Peru}

A RESERVE of 50,000 hectares $(123,554$ acres $)$ to protect the vicuña has been created in Peru by the Forest Service, on a high plateau (puna) 12,000 $\mathrm{ft}$. up in the mountains to the south-west of Lima. It lies between Nasca and Puquio and is called the Reserva Nacional de Pampa de Galeras. A remarkable aspect of its creation is that 8000 hectares of it were set aside for the vicuña by the indigenous community of the small village of Lucanas.

In October $1964 \mathrm{Mr}$ P. V. Pierrez, of FAO, discovered that there were some 1000 vicuña in the area, the largest known concentration anywhere in South America, which means that Peru probably has more than the combined total for Chile, Argentina and Bolivia, the other countries where they are found. The villagers were persuaded of the value to them of conserving the vicuña, with so much success that they agreed to set this land aside where there should be no inhabitants and no grazing.

With the aid of finance provided through the intervention of the Latin American Committee of the National Parks Commission of IUCN, Mr Pierrez conducted a training course for wardens, and there are now seven trained wardens with three assistants in the reserve. Management is in the hands of the Forestry Service, aided by a young biologist of the American Peace Corps, Stanley Taft.

Since Mr Pierrez first described the area in Ootober 1964, the numbers of vicuña have increased from 1000 to about 1500 , and at this rate of increase it should be possible to start cropping in two to three years, thus providing valuable fur and meat for the villagers. They will also benefit from the tourism that it is hoped to develop, for nowhere else can vicuñas be seen with certainty in such numbers. The reserve is bisected by a road, $20 \mathrm{~km}$. long, from which quite large herds can always be seen, and it is intended to build a guest house and encourage tourists.

As Mr Pierrez points out, it is not possible to persuade poor and hungry people to protect wild animals for their beauty or for science, but it can be done on economic grounds, as this success with the village of Lucanas has shown.

A resolution passed at the IUCN General Assembly congratulated the Peruvian government on the measures it has taken to conserve the vicuña and study its ecology, and urged the government to take similar measures for other important species, especially in the forests. 